水 文 · 水資源学 会誌

J. Japan Soc. Hydrol.\& W ater Resour.

$\underline{V}$ ol. 18, No. 6 (2005) pp. $681-687$

\title{
渓流河川における $\mathrm{pH}$ ・電気伝導率の自動連続観測
}

\section{A utomatic Continuous Observation of $\mathrm{pH}$ and Electric Conductivity in a Mountain Stream}

\author{
井上隆信 ${ }^{1)}$ 松下 拓 ${ }^{2)}$ 山田俊郎 ${ }^{1)}$ 松井佳彦3) \\ Takanobu INOUE TakuMATSUSHITA ToshiroYAMADA Yoshihiko MATSUI \\ 1) 豊橋技術科学大学建設工学系 \\ Dept. of Architecture and Engineering, Toyohashi University of Technology \\ 2) 岐阜大学工学部 \\ Faculty of Engineering, Gifu University \\ 3) 北海道大学大学院工学研究科 \\ Graduate School of Engineering, Hokkaido University
}

\begin{abstract}
酸性雨の影響等による水質变化を的確に捉え兴の現象を解明するためには, 水質の連続観測データが必要となる.pH と電気伝 導率 $(E C)$ は水質の代表的な指標であるが, 特に $\mathrm{pH}$ の連続観測は測定か灘しいため行われてこなかった . 本研究では, pH の連続 観測手法の確立を目的に, 岐阜県伊自良湖流入河川の伊自良川で, pH と ECについて, 2001年から 4 年間の長期間にわたり河川水 中にセンサーを設置して連続観測を行った . 連続観測による pH 值と採水した試水の $\mathrm{pH}$ 測定值では異なっていたが, 試水の $\mathrm{pH}$ 測 定值を用いて連続観測データを補正することで，降雨時を含めた長期間の pH の变化を連続的に観測することができた ．ただし， 降雨時に pH が低下した後の上昇時には, 連続観測值に一時間程度の遅れが生じていた . EC は, 補正することなく連続観測が可能 であった . 降雨時には, 他の溪流河川での観測と同樣に流量増加時のpH と EC の低下, 流量減少時の上昇が見られ，この変化を短 い時間間隔で観測することができた，融雪時には , pH の低下に対して EC が上昇する傾向も見られ，降雨時とは流出パターンが異 なり，降雨時よりも複雑な反応が生じている可能性が示唆された .
\end{abstract}

キーワード : 渓流河川 , pH，EC，自動観測，酸性雨

A utomatic continuous observation of water quality in a river is necessary to find changes in water quality which are caused by acid deposition. The automatic continuous observation of $\mathrm{pH}$ has not been conducted because it is difficult to obtain the accurate value, although $\mathrm{pH}$ and electric conductivity $(\mathrm{EC})$ are the major items of water quality. In this study, continuous observations of $\mathrm{pH}$ and EC were conducted with on-site sensors of $\mathrm{pH}$ and EC for 4 years since 2001 in the Ijira River, which is the main inlet of Lake Ijira located in Gifu Prefecture. Long-term pH variations including those in storm periods could be attained by correcting of the observed data by the sensor with the $\mathrm{pH}$ value obtained by the measurements of sampled $w$ ater in the laboratory. T here was about 1 hour of lag between the $\mathrm{pH}$ observed on site and that measured in the lab during $\mathrm{pH}$ recovery period after $\mathrm{pH}$ decrease in a storm event. Long-term continuous observation of EC could be carried out without any corrections. Decreases in $\mathrm{pH}$ were observed during snow melt periods as well as during storm in the Ijira River. The value of both $\mathrm{pH}$ and $\mathrm{EC}$ decreased during storm periods while increases in EC and decrease in $\mathrm{pH}$ were observed during snow melt periods, which suggested that there are some differences in runoff mechanisms.

Key words : Mountain stream, pH, EC, A utomatic observation, A cid deposition

$$
\text { I .はじめに }
$$

人間活動によってもたらされた地球規模の環境污 染の一つとして酸性雨があり, 弚の陸水環境への影 響は北欧等において1970年代に既に顕在化している (Leivestad and Muniz, 1976) . わが国では, 環境省
の20年間の対策調査の取りまとめとして，伊自良湖 に流入する河川において, pH の長期的な低下傾向 が見られると報告されている (酸性雨対策検討会 , 2004) . pH 低下の原因解明には, 谷の流出源や流域 内での反応を明らかにする必要がある . 短期的には 降雨時 (海老瀬, 1996) や融雪時 (Haapala et al.,

1) T441-8580 豊橋市天伯町雲雀ヶ丘 1-1 1-1 Hibarigaoka T empaku-cho T oy ohashi 441-8580, Japan

2) 社会基盤工学科 $=501-1193$ 岐阜市柳戶1-1 1-1 Y anagido Gifu, 501-1193 Japan

3）環境創生工学専攻 $=060-8628$ 札幌市北区北13条西 8 丁目 Kita 13, Nishi 8, Kita-ku Sappor o, 060-8628, Japan 
1975)に $\mathrm{pH}$ が低下しており，この現象解明にはア ウトプットである渓流河川水の $\mathrm{pH}$ の連続観測デー タが必要となる，渓流河川水のように，イオン強度 の低い水の $\mathrm{pH}$ を小数点以下二椼まで正確に測定す ることは非常に難しい(佐藤, 本橋, 1987).また， 正確に測定するために，渓流河川水を長期間にわた り頻度高く採水し，実験室に持ち帰るには，多大な 労力を要する.このため, 現地に $\mathrm{pH}$ センサーを設 置して連続観測することが必要であるが, センサー の出力が長期間安定しないこと, センサーのメンテ ナンスが必要なことから $\mathrm{pH}$ を直接測定した研究例 (Komai et al., 2002) は少ない.

また, 電気伝導率 $(E C)$ は, 大まかに水中の溶存 イオン量を表す水質項目であり，測定が容易なこと から連続観測は実施されている.しかし, $\mathrm{pH}$ と EC は異なった水質項目であり，ECから $\mathrm{pH}$ を推定する ことはできず, $\mathrm{pH}$ の変化を見るためには, pH の連 続観測が必要になる。

本研究では, 渓流河川に $\mathrm{pH}$ センサー, EC セン サ一等を設置して，直接渓流河川水を連続観測し， そのデータの有効性と, 得られた結果について検討 を行った。

\section{II. 研究方法}

\section{1. 調査対象地点の概要}

岐阜県の南部に位置する伊自良湖の流入河川を調 査対象とした . 調査地点の概要を図 - 1 に示す . 伊 自良湖は, 東アジア酸性雨モニタリングネットワー

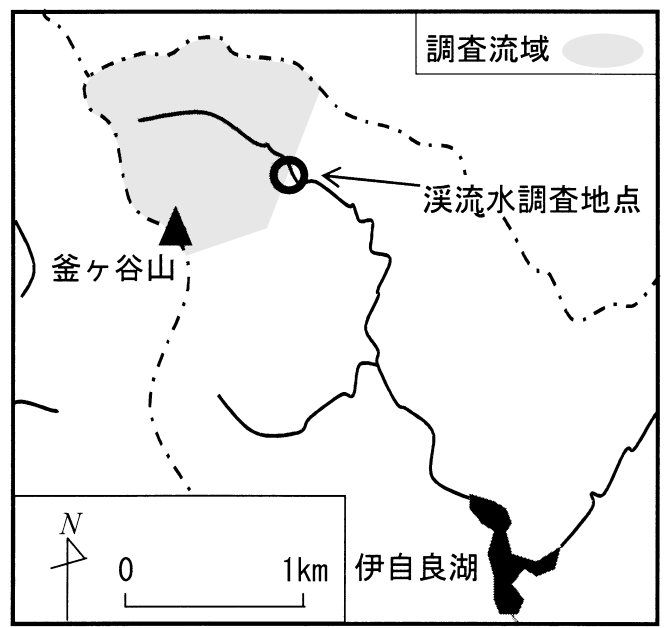

図 - 1 調査地点の概要.

Fig. 1 Map of studied area.
クにおいて, 我が国のモニタリング地点として，島 根県の蟠竜湖とともに指定されている.伊自良湖に は, 伊自良川と孝洞川の 2 河川が流入しているが， 孝洞川は晴天時に水が涸れるため, 主要河川である 伊自良川を調査対象とした . 酸性雨モニタリング ネットワークの調査地点は, 伊自良湖流入直前の地 点であるが, 弚の上流に向かって，伊自良青少年の 家, 森林学習展示館, キャンブ場, コテージ等が点 在している．また，砂防ダムも存在する．このため， 本研究における調査地点は, 上流に人為污染源や砂 防ダムのない地点とし, 水位センサー設置地点で流 量観測が可能であること，データロガー等が洪水時 にも流されないように設置できる場所があることを 条件として選定し，伊自良湖流入地点から約 1.7 $\mathrm{km}$ 上流とした。調査地点の流域面積は, $0.92 \mathrm{~km}^{2}$ である .

集水域の地質は, ジュラ紀-白亜紀最前期の美濃 帯堆積岩コンプレックスに属する根尾メランジの チャートに分類される (脇田, 1991). 植生は, ス ギ・ヒノキ・サワラ植林の地域が最も多く，モモツ ツジ・アカマツ群集, コナラ群落も存在している(環 境庁，1999)。(ほ集水域に沿ってハイキングコー スが整備されているが, トイレもなく人為的污染源 はない .

\section{2 . 調査方法}

調査地点に, 水位, 水温, 電気伝導率 $(E C), p H$ を自動観測できる装置を2000年11月初旬に設置し， 自動測定を開始した。記録・制御装置 (CR-10X, Campbell Scientific.Inc.) は, 10秒間隔の瞬間值の 10分間平均値を記録するように設定した . 各セン サーのマニュアルでは, pH センサー (CSIM11, Cambell) は土 pH 0 2以下, ドリフトは一週間 2 $m V$ 以下の精度, EC・水温センサー (247W-L 25, Cambell) はECが $\pm 10 \%$ 以下, 水温が $\pm 0.4^{\circ} \mathrm{C}$ 以下, 水位 (PDCR-940, Drag) センサーは土 0 1\%以下の 精度である $\mathrm{pH}$ センサー, $\mathrm{EC} \cdot$ 水温センサー，水 位センサーは, 水が滞留しないように先端をメッ シュ状にした塩ビ管を岸から河川内に延ばし，光の 中に入れた . また, $\mathrm{pH}$ センサーは校正が必要なた め, 塩ビ管からセンサーの出し入れが簡単にできる 構造とした . 電力源は, ソーラーパネルと $12 \mathrm{~V}$ の自 動車用バッテリーを用いて稼動させた . 調査地点に は自動観測装置とともに自動採水器 $(6700$, ISCO ) を設置した . 自動採水器の運用は調査途中で変更し， 
2001年は 1 日 1 回の採水，2004年は 2 日に 1 回の採 水を行った . また，2002年と2003年は主に降雨時採 水に用いた。

現地調査は原則として週 1 回(2001〜2003年)，ま たは 2 週間に1回 (2004年) 行い, データと自動採 水器内のサンプルの回収, 流量観測, EC の測定, 標準溶液を用いた $\mathrm{pH}$ センサーの測定值の確認を 行った . 大幅に $\mathrm{pH}$ がずれた場合には，センサーの 出力である電位差を $\mathrm{pH}$ に変換する係数を変更して 校正を行った . 2001年から2004年の測定期間中， 2002年 7 月15 19日には, 観測地点に最も近い岐阜 県平井のアメダス観測所で総降雨量 $215 \mathrm{~mm}$, 最大 1 時間降雨量5 $\mathrm{mm}$ が観測された降雨 (岐皁地方気 象台，2002) があり，センサーが流されたため 2 ヶ 月程度データが欠測となった .また，2003年にも $\mathrm{pH}$ 電極の破損, データ取り込みプログラムの設定 ミス等がありデータを取れなかった期間があった . 2001年と2004年は，1年間連続して観測ができた .

\section{3. 分析 ·解析方法}

採取したサンプルは, 実験室に持ち帰り速やかに $\mathrm{pH}$ を分析した後冷蔵保存し, 他の水質項目の分析 に供した $\mathrm{pH}$ の測定は, 流通形セルの $\mathrm{pH}$ 計 $(\mathrm{pH}$ 計：HM-30V，ガラス電極：HGS-2005, 比較電極： FA R-201A，東亜電波)を用いたフロー $\mathrm{pH}$ 測定法で 行った .このフロー $\mathrm{pH}$ 測定法は, イオン強度の低 い渓流水の $\mathrm{pH}$ を精度良く安定的に測定することが 可能である (松本，2000）。

$\mathrm{pH}$ センサーによる連続観測データには，長期的 に $\mathrm{pH}$ が低下するドリフトが見られた . また，渓流 河川水のイオン強度が低いため, 校正に用いる $\mathrm{pH}$ $4.01,686,9$ 18の標準緩衝液では正しい值を示す ものの , ハンディータイプの pH 計 (HM-14P，東亜 電波)，実験室に持ち帰り測定したフロー $\mathrm{pH}$ 測定 法での值とも異なっていた .このため, 実験室で測 定したフロー $\mathrm{pH}$ 測定法の值を正しい値とし，セン サー出カのドリフトが時間に対して線形に変化して いると仮定し，1週間ごとや1日1回採水した水に ついてフロー $\mathrm{pH}$ 測定法で測定した $\mathrm{pH}$ を用いて， 連続観測した $\mathrm{pH}$ を補正した。

水温 $\mathrm{t}\left({ }^{\circ} \mathrm{C}\right)$ のときの電気伝導率 $\mathrm{EC}(\mathrm{t})(\mathrm{mS} / \mathrm{m})$ と， $25^{\circ} \mathrm{C}$ に換算した EC $(\mathrm{EC}(25))(\mathrm{mS} / \mathrm{m})$ の間には以下 の関係がある .

$$
E C(t)=E C(25) \times(1+\alpha(t-25))
$$

この式を用いて EC(25)の值を求めた . 係数a の值

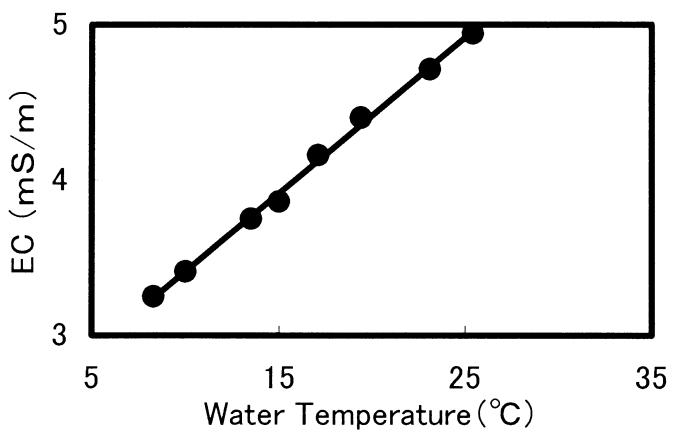

図 - 2 伊自良川の電気伝導率の水温による変化. Fig. 2 Relationships between electric conductivity and $w$ ater temperature of Ijira river $w$ ater.

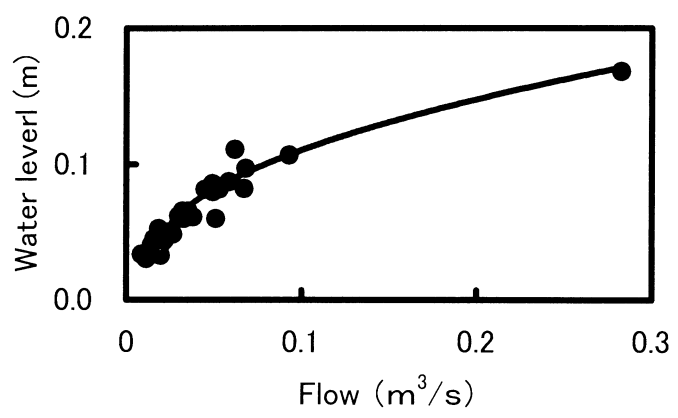

図 - 3 測定水位と流量の関係 .

Fig. 3 Relationships between water level and flow rate.

は, 図-2に示すように, 採取し冷蔵保存した試水 について, 温度を上昇させながら, 温度と EC を測 定し, 弚の傾きとy 切片の值から求めて, 0 .020を 採用した。

現地観測時に測定した流量と，光の時の連続観測 水位の関係を図 - 3 に近似曲線とともに示した . 高 流量時の測定回数が少ないが, 流量 $\mathrm{Q}\left(\mathrm{m}^{3} / \mathrm{s}\right)$ は水位 $\mathrm{h}(\mathrm{m})$ の 2 次関数として表すことができ，この水位 流量曲線を用いて, 連続観測水位から流量を求めた . ただし，2002年 7 月10日の洪水の後は河床断面が変 わったこと，2004年 5 月からは, 流量測定地点を変 更したことから，新に同樣の水位流量曲線を求めた .

III. 結果及び考察

1.pH 連続観測データの信頼性

1 ) 試水放置の影響

電力源はソーラーパネルだけであり，電力容量の 


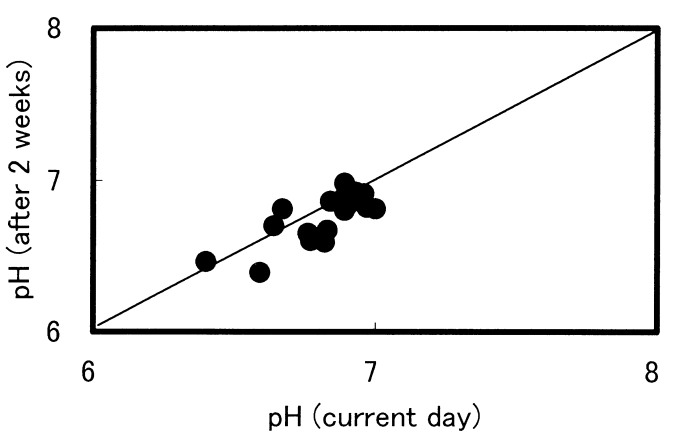

図 - 4 当日測定と 2 週間後測定の $\mathrm{pH}$.

Fig. 4 Relationships between $\mathrm{pH}$ measured 2 weeks after the sampling and $\mathrm{pH}$ measured on the cur rent day of the water sampling.

問題から自動採水器で採取した試水の保存用クー ラーボックスを設置することができなかった .この ため, 自動採水器で採取した試水は, 回収するまで 最長で 2 週間，採水器の中に放置されている．この 保存期間の $\mathrm{pH}$ の変化がないかどうかを検証するた めに, 調査時には採水をして持ち帰るとともに，自 動採水器でも採水を行い, 次の調査時に回収した . 持ち帰った後すぐに測定した $\mathrm{pH}$ と自動採水器の中 に2 週間放置した後に持ち帰って測定した $\mathrm{pH}$ との 関係を図 -4 に示した.相関係数は0 .76, 最大で 0 23の違いであり，2週間放置していることによる $\mathrm{pH}$ への影響はほぼなかったといえる.污濁した河 川水であれば, 藻類が増殖すると $\mathrm{CO}_{2}$ 濃度が減少し $\mathrm{pH}$ が上昇する等変化するため，現地で測定するか， 採水後直ちに測定する必要がある．観測を行った伊 自良川では光のような生物の影響が少ないため, 2 週間後においても $\mathrm{pH}$ にさほど変化が生じなかった ものと考えられる . また , 生物の影響は水温の高い 夏季に大きくなると考えられるが, 気温の高い夏季 に差が大きくなることもなかった . 試水の性質に よって見極める必要があるが, 今回の調査対象とし た伊自良川では，自動採水器で採水した試水でも， 正確な $\mathrm{pH}$ を測定することができた .

\section{2 ) pH センサーの応答性}

連続観測センサーの $\mathrm{pH}$ の変化に対する応答性に ついては, 降雨時に 1 時間に 1 度自動採水器により 採水したデータを用いて検証を行った . 図－5には， 降雨時の連続観測による $\mathrm{pH}$ の变化と，1 時間に1

回採水した試水について実験室で測定した $\mathrm{pH} に つ$ いて，2002年 6 月30日から 7 月 3 日の降雨時観測時

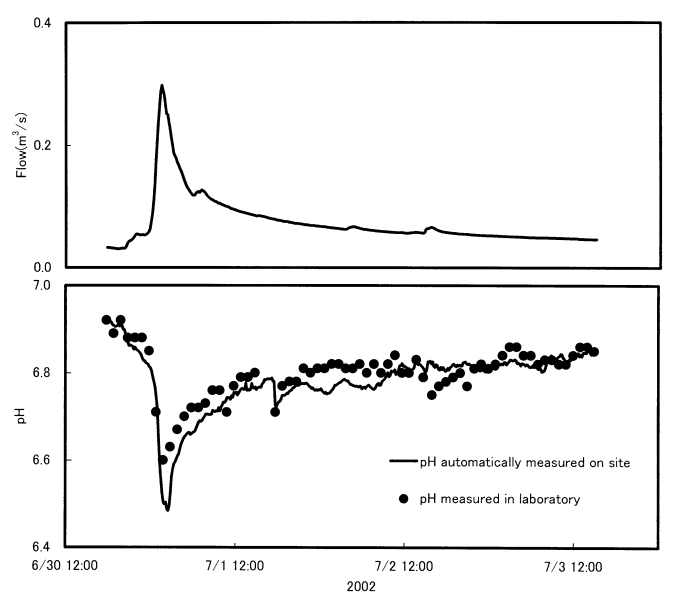

図 - 5 連続観測センサーの $\mathrm{pH}$ 応答性 .

Fig. 5 Characteristics of $\mathrm{pH}$ response of the continuously observed sensor.

のデータを例に示した .この降雨時観測では，毎日 自動採水器で採水した試水を回収に行き, 途中 2 時 間の欠測があるが合計で69サンプルを採水した .こ の連続観測の $\mathrm{pH}$ は, 自動採水器による1 時間間隔 の採水の開始時の 6 月30日16時と終了時の 7 月 3 日 15時に採水した試水のフロー式 $\mathrm{pH}$ 測定法での値を 用いて補正した . pH が最も低下したときで炎の差 が最大になり，現地観測データは6 49 ，実験室での 測定値は6 .63と差が0 14であった . pH 低下時は， 現地観測データと実験室の測定值とで時間差はな かったが, $\mathrm{pH}$ 上昇時には，1時間程度，現地観測 データに遅れが生じていた，厳密には，現地観測 データの 3 時の值は, 2 時50分から 3 時までの平均 值であり，ここでも 5 分の時間差は生じている．採 水間隔が1 時間であったため, 乥れより短い時間で はわからないが，長期間の連続観測データとみれば， 無視しうる程度の時間遅れと考えられる .ただし， 降雨時の他の水質項目との関係や流量との関係を見 るときなどには注意が必要である．

これらのことから，伊自良川の観測地点において は，渓流河川水中にセンサーを設置して測定し，採 水した試水を測定した值で補正することで，pH の 変化を連続的に観測することができた .この手法は， 他の渓流河川にも応用可能と考えられる .

2 . 渓流河川の $\mathbf{p H} \cdot \mathbf{E C}$ の変化

図 -6 には，1年間の連続観測ができた2001年と 

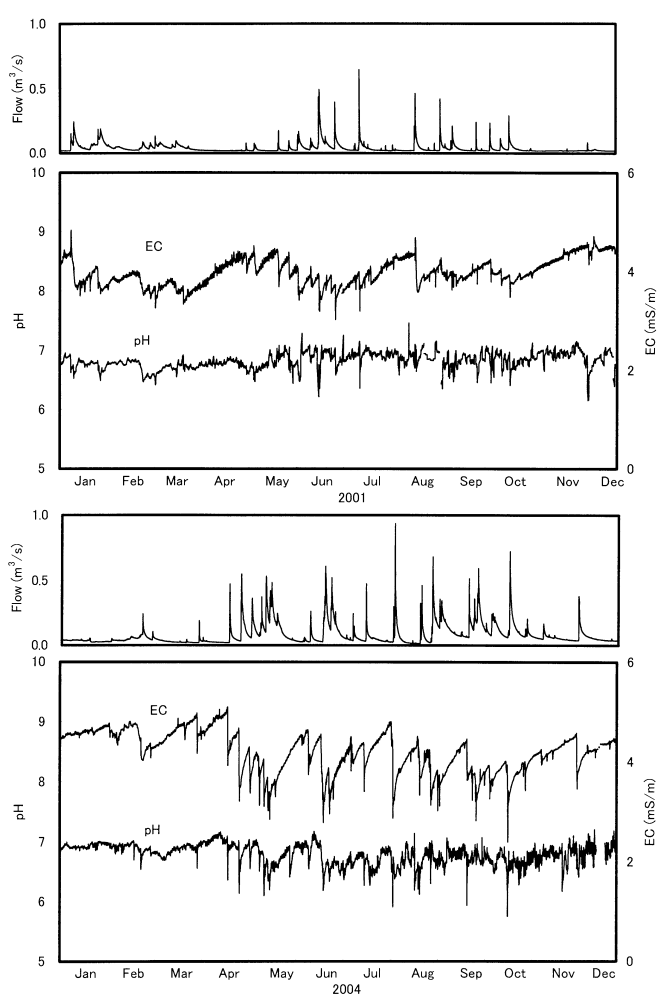

図 - $6 \mathrm{pH}$ と電気伝導率の年変化 (2001年 (上段) 2004年 (下段)).

Fig. $6 \mathrm{~V}$ ariations in $\mathrm{pH}$ and electric conductivity in 2001 (upper) and 2004 (lower).

2004年の pH と EC の変化を示した . ここで示した 值は, 10分間隔のデータ 6 個を単純平均して, 1 時 間の值にしてある .

観測した伊自良川の $\mathrm{pH}$ は，ほぼ 7 程度であるが， 降雨に伴う流量増大時に低下している.降雨前に比 べて，最大低下時には，pH が1 . 0 程度低下した。 2001年は, 後で詳述するが, 1 月から 3 月にかけて $\mathrm{pH}$ が低くなっていた．しかし，2004年は光のよう な傾向は見られなかった . 2001年には前年末に降っ た雪がなかなか解けず，3 月初旬まで積雪があった . これに対して2004年は雪がほとんど降らず，積雪期 間も短かった . 2001年は融雪により，pH が低下し ていたものと考えられる.特に，2月末からは気温 も上がり，流量も増えていたことから，このときの $\mathrm{pH}$ の低下は融雪によるといえる .

伊自良川のEC は，降雨時に急激に低下し，光の 後緩やかに上昇することを繰り返している．降雨の
間隔が短くなると，EC は降雨前に回復する前に次 の降雨により低下するため，2001年の 5 月〜 6 月や 2004年の 4 月のように長期的低下傾向が見られる . 降雨がない期間に EC は上昇しているが，定常状態 になる前に次の降雨により低下した . 2001年は $\mathrm{pH}$ と同樣に 1 月から 3 月にECも低下していたが， 2004年は关のような傾向は見られなかった .

$\mathrm{pH}$ の単純平均值は, 2001年が6 83, 2004年が 6.79 であった . 2002年と2003年は欠測データがある ため単純には比較できないが, とちらも6 80であっ た . 2001年から2004年で $\mathrm{pH}$ が0.04低下しているが， 図 - 6 に示したように降雨時には $\mathrm{pH}$ が1程度低下 し, 積雪が多ければ, 弚の期間の $\mathrm{pH}$ は低くなるた め, 酸性雨検討委員会の報告にあるように $\mathrm{pH}$ が長 期的に低下しているかどうかを見極めるためには， さらに長期間の観測が必要である.

EC の単純平均值は, 2001年か3 $.99 \mathrm{mS} / \mathrm{m}, 2004$ 年が $21 \mathrm{mS} / \mathrm{m}$ であった . また , 欠測データがあ るが，2002年は4 $.06 \mathrm{~ms} / \mathrm{m} ， 2003$ 年 は4 $.43 \mathrm{mS} / \mathrm{m}$ であった . 図ー6に示したように，無降雨期間には ECの上昇が見られるため, 降雨量, 降雨頻度, 積 雪量等により年平均値は変化する．2001年は2004年 に比べて，1月から 3 月にかけて低かったことに起 因して，ECの年平均値が低くなったものと考えら れる。

\section{3. 降雨時の変化}

降雨時の $\mathrm{pH}, \mathrm{EC}$ と流量の関係について，2001年 6 月30日 6 時から 7 月 1 日24時の降雨時の変化を図 - 7 に示した . 近くのアメダス観測所では 6 月30日 の 6 時から 7 月 1 日の 1 時までに $67 \mathrm{~mm}$ の降雨を 観測している (岐阜地方気象台). 降雨前の $\mathrm{pH}$ は 6 .95であったが , 流量の増加とともに低下し, 最低 值は最大流量時の6 56であり，039低下した．弚の 後流量の減少とともに $\mathrm{pH}$ は上昇した . 流量減少時 は, 増加時に比べて同じ流量での $\mathrm{pH}$ は低くなり， ヒステリシスを描いた．ECは，同樣に降雨前の $3.72 \mathrm{mS} / \mathrm{m}$ から流量の増加に伴い低下し, 最大流 量時には3.01 mS/m の最低值になった . 谷の後, 流量の減少に伴い上昇したが, 流量増加時と減少時 を比べると，同じ流量のときにはほぼ同じ EC の值 になった . 渓流河川において降雨時に $\mathrm{pH}$ と EC が 低下する現象は, 屋久島の宮之浦川 (海老瀬 , 1996) 等でも観測されているが, 伊自良川における連続観 測期間中の降雨時には, ほぼ同樣の変化が見られる 

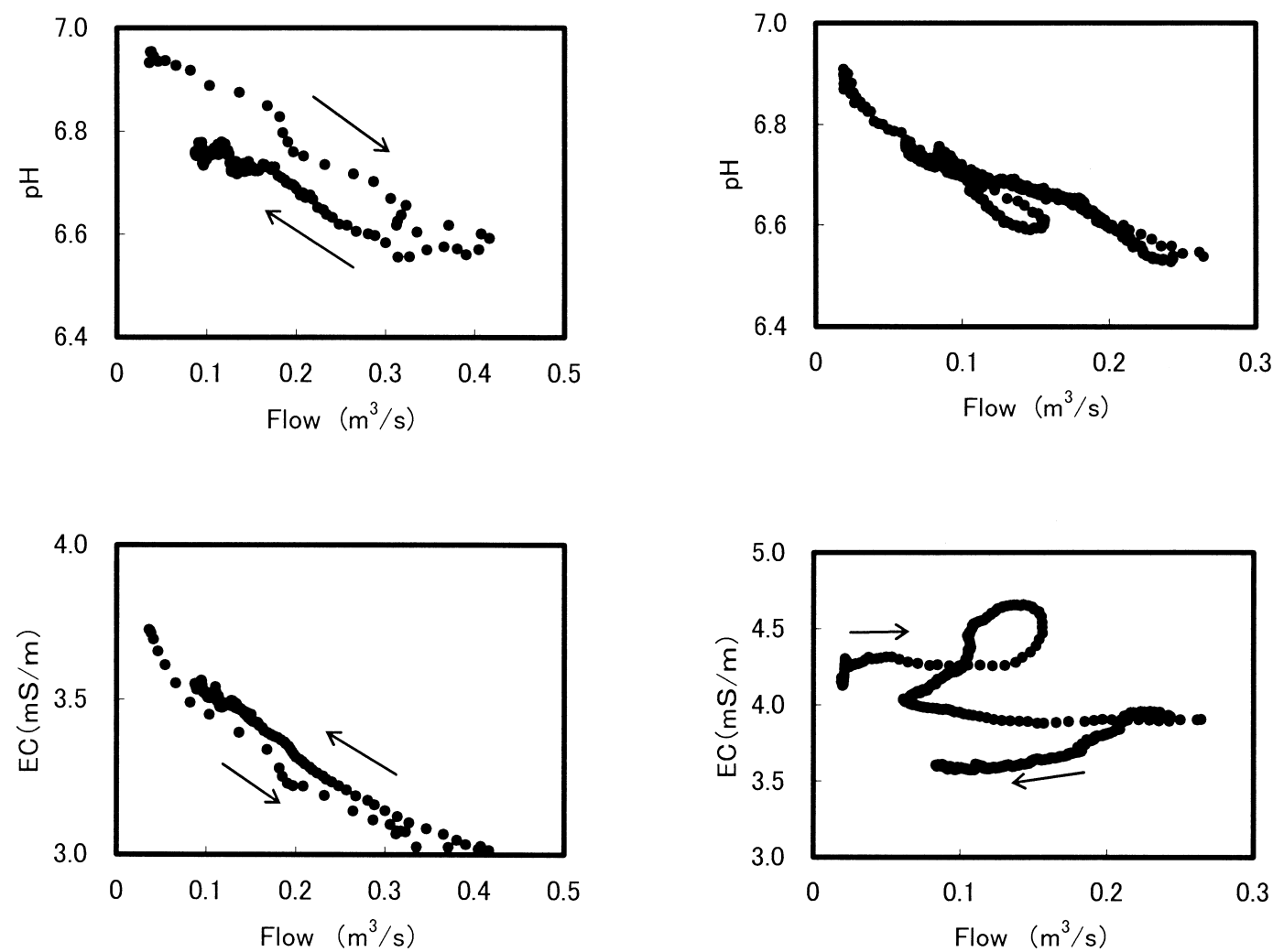

図 - 7 降雨時の流量と $\mathrm{pH}$, 電気伝導率との関係.

Fig. 7 Relationships between $\mathrm{pH}$ and flow rate (upper) and between EC and flow rate (lower) during a storm period.

ことが多かった $\cdot \mathrm{pH}$ と EC で降雨時の変化に違い が見られたが, この解明のために, イオン組成の変 化等，より詳細な観測が必要になる。

\section{4 . 融雪時の変化}

2001年は, 前年の末に降雪があり, 光の後 3 月初 旬まで積雪があった .この 4 年間では，2001，2002， 2003年は一度に $50 \mathrm{~cm}$ 以上積雪があったが，2004年 の積雪量は少なかった . また, 気温が上昇するとす ぐに解け，2001年は 3 月初旬まで積雪があったもの の，2002年は 1 月初旬から 2 月中旬まで, 2003年は 2月上旬までであった .このように，積雪が観測さ れる年とされない年があった . 流量変化に伴う $\mathrm{pH}$ と電気伝導率の変化を2001年 1 月 9 日から13日の期 間について図－8に示した . 融雪時には, 流量の増 加に伴い $\mathrm{pH}$ も低下し, 流量の減少に伴い再び $\mathrm{pH}$ が上昇している.このとき $\mathrm{pH}$ は6 .90から6.53まで
図 - 8 融雪時の流量と $\mathrm{pH}$ ，電気伝導率との関係， Fig. 8 Relationships between $\mathrm{pH}$ and flow rate (upper) and between EC and flow rate (lower) during a snow melt period.

0.37 低下した .これに対して，電気伝導率は流量増 加時には変化せず，流量最大時から減少初期に上昇 し，弚の後の流量の減少に伴い低下する傾向がみら れた .このようなループを描くEC の変化は他の融 雪時にもみられた，融雪時には，流出水の流出経路 や土壌との接触時間が降雨時とは異なることにより， 単純に地下流水成分か降雨によって希釈されるだけ ではなく，より複雑な反応が生じていると考えられ る、観測を行った伊自良川では，積雪期間は短く， 多雪地域とは異なった現象が生じている可能性もあ る。

\section{IV . 結 論}

本研究では，伊自良川に設置したセンサーを用い て長期間の $\mathrm{pH}$ と電気伝導率の連続観測について検 討を行い, 以下の知見を得た .

1 ) $\mathrm{pH}$ は, 連続観測值と採水した試水をフロー 
$\mathrm{pH}$ 測定法で測定した值とでは異なっていたが， フロー $\mathrm{pH}$ 測定法で測定した值で補正すること で降雨時を含めた変化を観測することができた . EC は, 補正することなく連続観測が可能で あった。

2 ) 伊自良湖流入河川で長期間観測した結果, 融 雪期と降雨時に pH の低下がみられた .

3 ) 降雨時には流量の増加に伴い pH , EC ともに 低下し, 流量の減少時に増加する変化を短い時 間間隔で観測することができた．融雪時には， $\mathrm{pH}$ の低下に対して EC が上昇する傾向も見ら れ, 降雨時に比べて複雑な反応が生じている可 能性が示唆された .

土壤, 基盤岩石, 植生が異なる他の渓流河川にお いて，降雨時や融雪時も含めて $\mathrm{pH}$ を自動連続観測 することで, $\mathrm{pH}$ 低下の原因の解明につながると考 える.また，長期的な $\mathrm{pH}$ の変化を早期に発見する ことも可能である .

謝辞 : 本研究を実施するにあたり, 日生財団より研 究助成を頂いた. また, 調査及び分析には岐阜大学 では舩越修爾氏，竹田祐平氏，成田健太郎氏，豊橋 技術科学大学では宮田章史氏の協力を得た . 記して ここに感謝の意を表します。

\section{参考文献}

海老瀬潜一(1996)：屋久島渓流河川の晴天時・降雨 時水質への酸性雨の影響, 環境科学会誌, $9, \mathrm{pp}$. 377-391.

岐阜地方気象台：e -気象台（ホームページ）.

Haapala, H., Sepponen, P. and Meskus, E. (1975) : Effect of spring floods on water acidity in the Kiiminkijoki area, Finland, OIKOS, 26, pp. 26-31.

環境庁 (1999) : 第 5 回自然環境保全基礎調査植生調 査

Koami, Y ., U memoto, S. and Inoue, T . (2002) : A pplication of an automatic sampling and measurement sy stem to a mountainous stream investigation during rain event, Water Science and Technology, 45(9), pp. 213-218.

Leivestad, H., and Muniz, I. P. (1976) : Fish kill at low $\mathrm{pH}$ in a norwegian river, Nature, 259, pp. 391392.

松本光弘 (2000) : 雨水の $\mathrm{pH}$ 測定法, 酸性雨研究と 環境試料分析（佐竹研一編）, pp.9-27, 愛智出版， 2000.

酸性雨対策検討会 (2004)：酸性雨対策調査総合取り まとめ報告書 .

佐藤弦・本橋亮一(1987) : pH を測る, 丸善.

脇田浩二(1991) : 谷汲地域の地質, 地質調査所.

(受付：2005年 4 月27日，受理：2005年 8 月19日) 